\title{
Identification and sequencing of bla CTX-M genes in clinical isolates of Klebsiella pneumoniae isolated from Milad hospital
}

\author{
Samar Sedaghatpishe ${ }^{1(i)}$, Maryam Ghane ${ }^{2}$ (D) Laleh Babaeekhou $^{3}$ \\ ${ }^{1}$ Department of Biology, Islamshahr Branch, Islamic Azad university, Islamshahr, Iran \\ ${ }^{2}$ Corresponding author; Department of Biology, Islamshahr Branch, Islamic Azad university, Islamshahr, Iran \\ Tel:+982156358105_Email: ghane@iiau.ac.ir,maryamghaneh@yahoo.com \\ ${ }^{3}$ Department of Biology, Islamshahr Branch, Islamic Azad university, Islamshahr, Iran
}

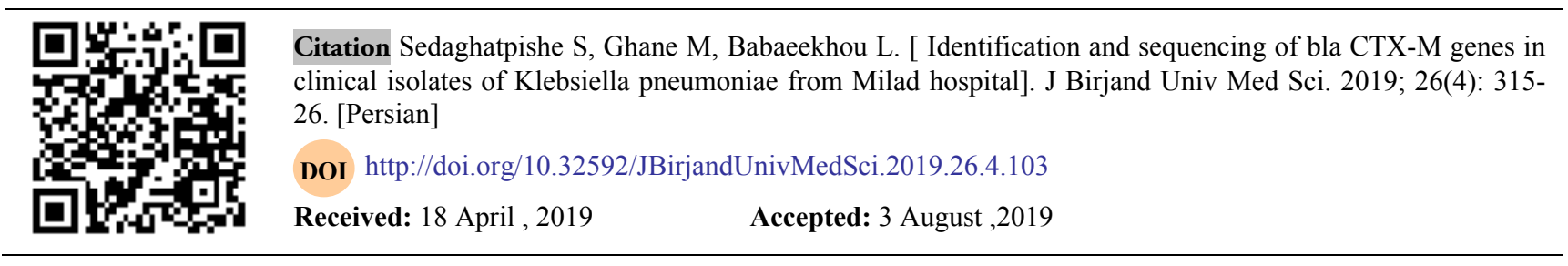

\begin{abstract}
Background and Aim: Klebsiella pneumoniae is one of the most important causes of nosocomial infection which has recently received much attention due to its antibiotic resistance. The aim of the present study is the identification and sequencing of $b l a_{\mathrm{CTX}-\mathrm{M}}$ genes in clinical isolates of $K$. pneumonia isolated from Milad Hospital in Tehran.
\end{abstract}

Materials and Methods: In this descriptive cross-sectional study, first, antibiotic resistance of $100 \mathrm{~K}$. pnuemoniae isolates to cephalosporins was performed by agar diffusion method; then $b l a_{\mathrm{CTX}-\mathrm{M} \text { group2 }}$ and $b l a_{\mathrm{CTX}-\mathrm{M} \text { group9 }}$ resistance genes were identified by PCR. Genotyping was performed based on the sequence of these genes and the dendrogram was drawn using the Mega 6 software (version 6).

Results: According to the antibiotic sensitivity testing, the amount of resistance to cephalosporins was between 30 and 54 percent. Overall, $5 \%$ of isolates had $b l a_{\mathrm{CTX}-\mathrm{M} \mathrm{group} 2}$ and $8 \%$ of isolates had bla $a_{\mathrm{CTX}-\mathrm{M} \mathrm{group} 9}$ as well as, the genotyping results showed that in this study bla ${ }_{\text {СтX-M group2 }}$ sequence with the sequences in the global database (NCBI) had little similarity, and the bla $a_{\text {CTX-M group9 }}$ gene sequence was similar to the bla СТХ-M-14 sequence gene of $E$. coli.

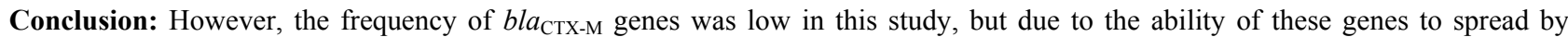
mobile genetic elements among enterobacteriaceae, it is considered alarm in the development of drug resistance among $K$. pneumoniae.

Key Words: Klebsiella Pneumoniae; Genotyping; Beta-Lactamase; Drug Resistance 


\title{
شناسايى و توالىيابى خنهاى bla كلبسيلا بنومونيه جدا شده از بيمارستان ميلاد
}

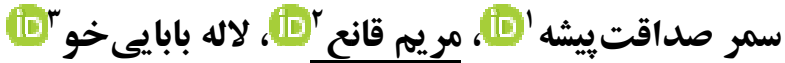

\section{جكيده}

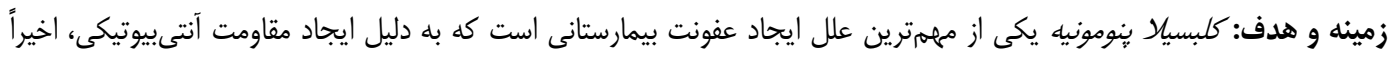

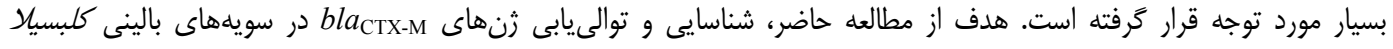

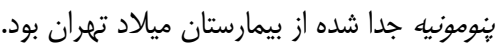

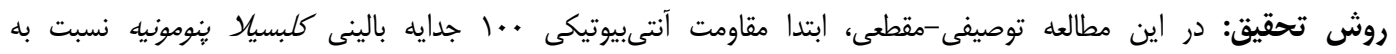

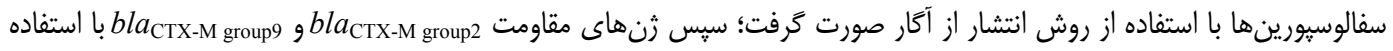

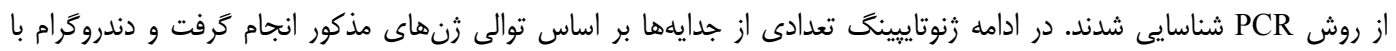
استفاده از نرمافزار مكا (نسخه و) رسم شدان.

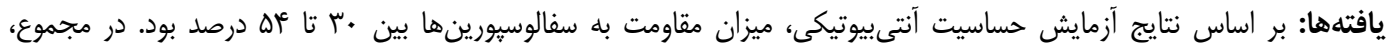
ه درصد جدايهها داراى زن bla

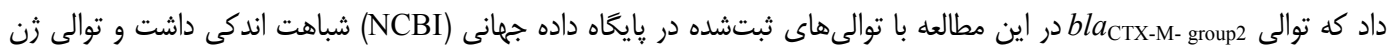

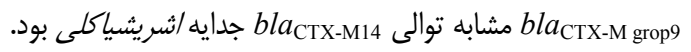

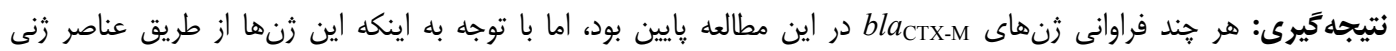

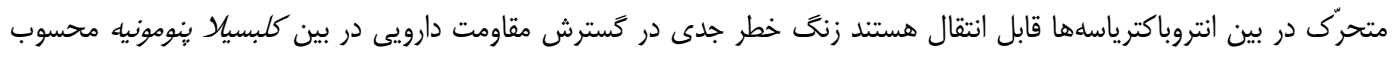
وازمهاى كليدى: كلبسيلا بنومونيه؛ زنوتاييينگ؛ بتالاكتاماز؛ مقاومت دارويى

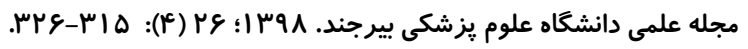
دريافت:

' ' كروه زيستشناسى، واحد اسلامشهر، دانشكاه آزاد اسلامى، اسلامشهر، ايران

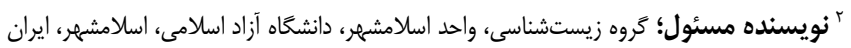

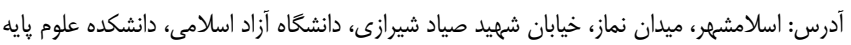

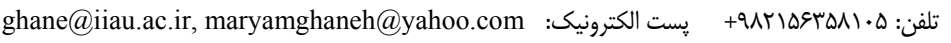
" "كروه زيستشناسى، واحد اسلامشهر، دانشكاه آزاد اسلامى، اسلامشهر، ايران 
آنزيمهاى كروه CTX-M كروهى از بتالاكتامازها هستند

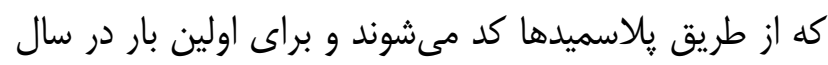

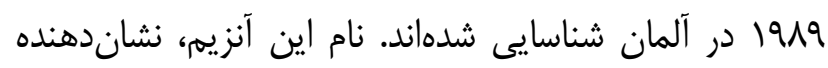

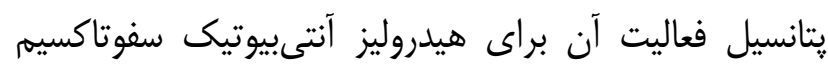

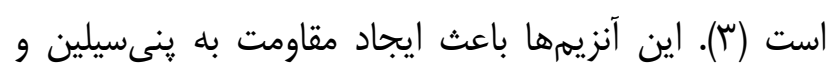

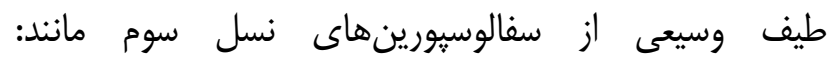

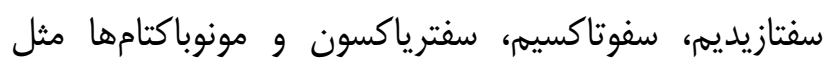

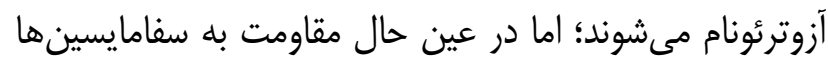

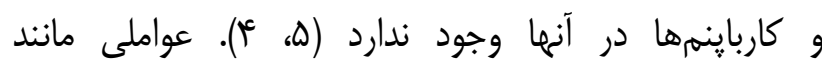

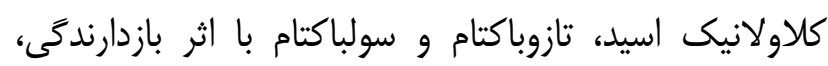

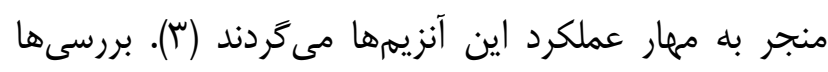

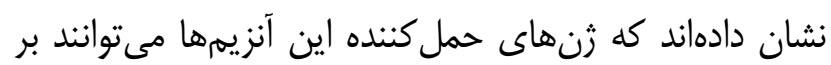

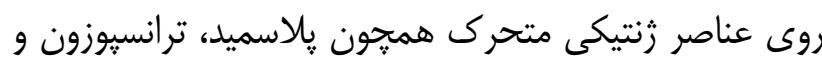

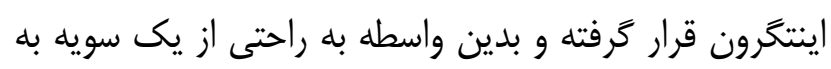

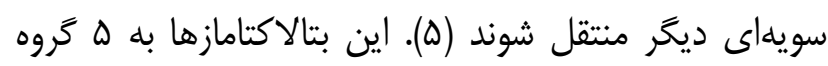

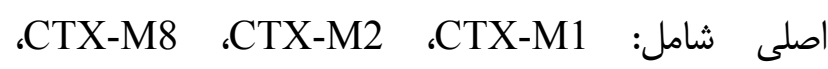
C CTX-M25 و CTX-M9

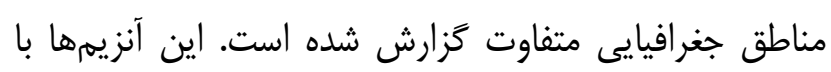

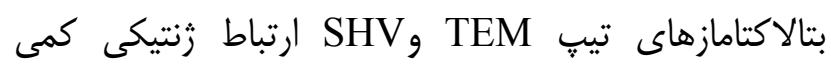
دارند، اما شباهت زيادى با آنزيم كروموزومى AmpC دارنى

تاييينى انتروباكترياسهها از نظر إييدميولوزى اهميت

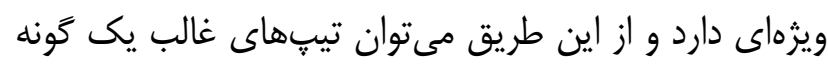

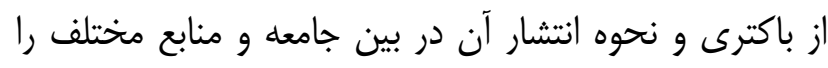

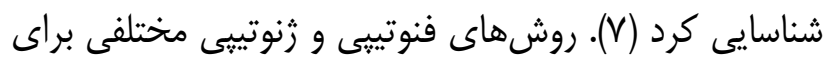
تاييينگ باكترىها وجود دارد كه در فر اين ميان SLST) (Single locus sequence typing) دقيق و مطمئن در تاييينگ باكترىها به حساب مى آيد (1).

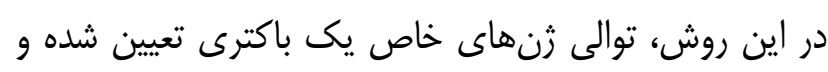

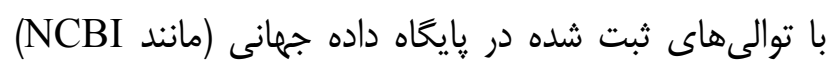

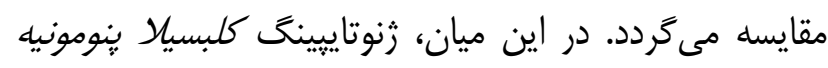

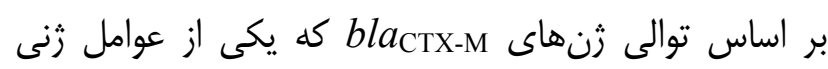

مقله

كلبسيلا بنومونيه، جزئى از ميكروفلور طبيعى بدن انسان

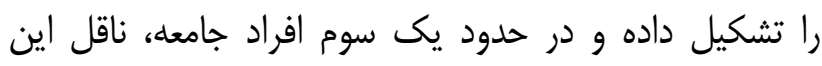

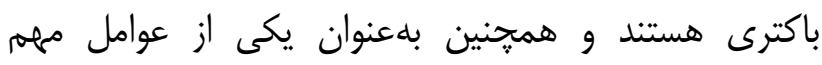

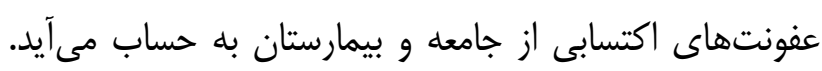
اين باكترى سبب ايجاد طيف وسيعى از عفونتهان إنها شامل:

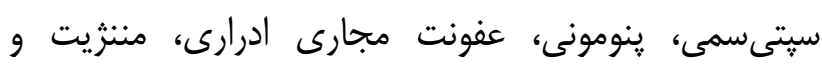

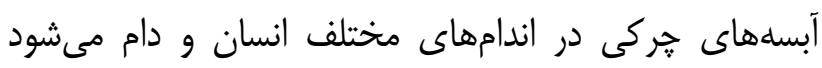

سفالوسيورينها داروهاى اصلى و يركاربرد در درمان

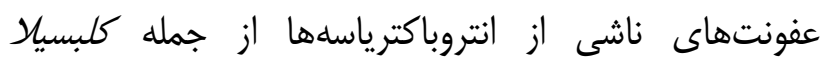

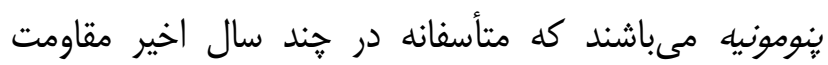

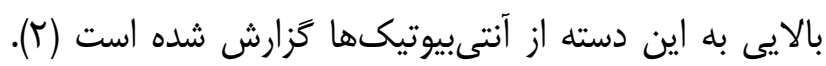

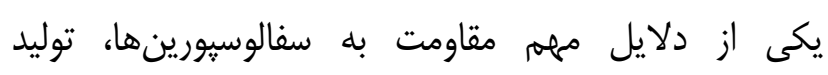

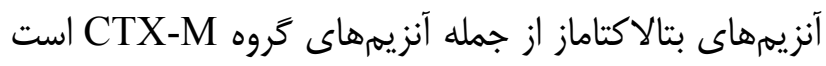

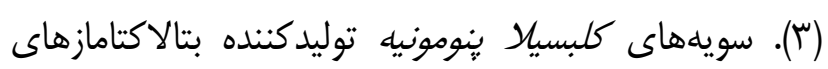
وسيعالطيف (ESBL)، از لحاظ بالينى بسيار با اهميت هستند؛

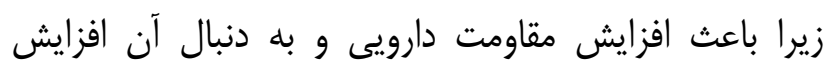

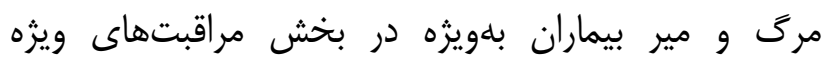

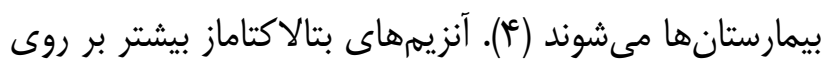

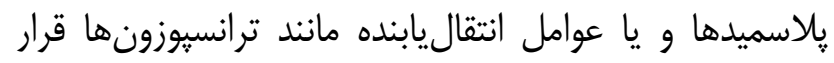
داشته و بلهور سريع در بين سويههاى باكتريايى انتشار

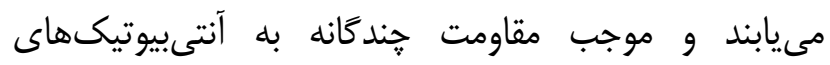

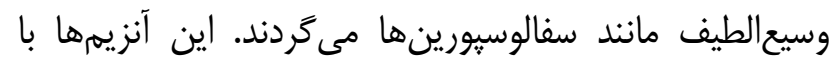

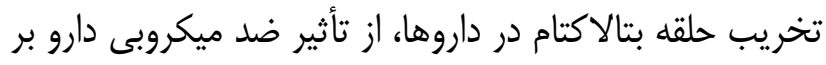

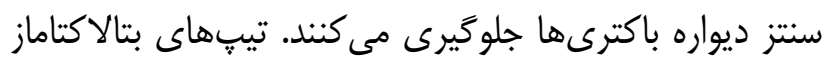

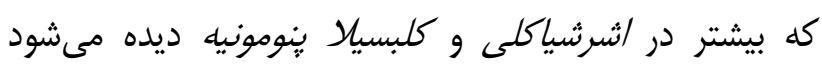

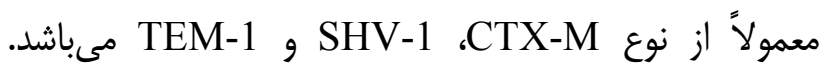
باكترىهاى حامل اين بتالاكتامازها كه بهعنوان جدايههاى

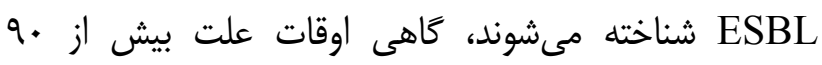

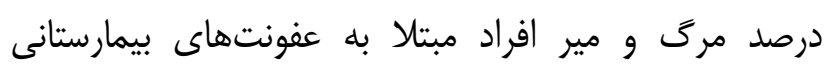
هستند (ه). (هرمد 


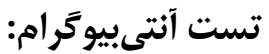

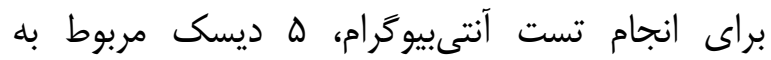

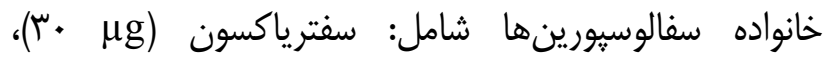

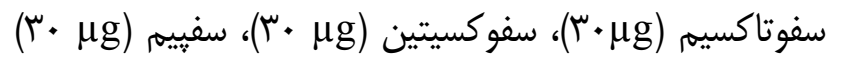

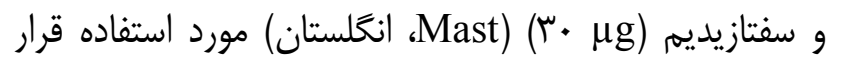

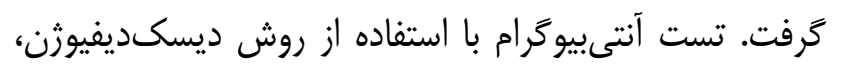

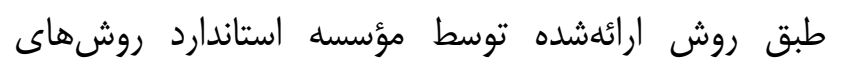

آزمايشگاهى (CLSI) انجام شد (I) (I).

\section{استخراج DNA: رماج}

استخراج DNA به روش جوشاندن براى همه جدايهها

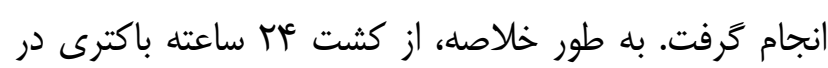

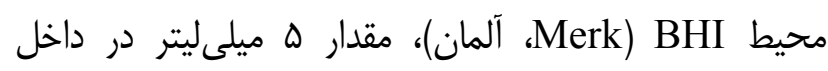

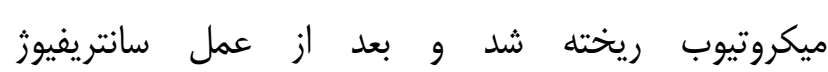
)

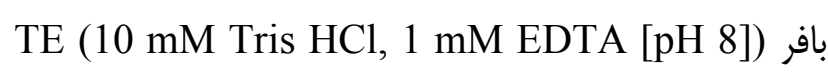

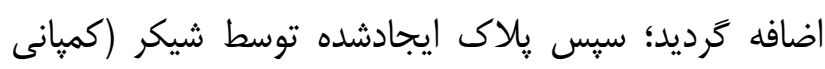
IIKA در دماى هو درجه سانتيگراد در داخل بنمارى (فاتر الكتريك،

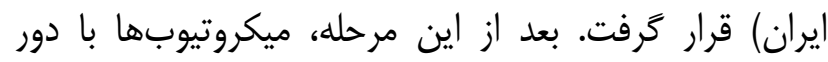

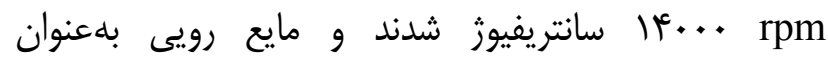
DNA

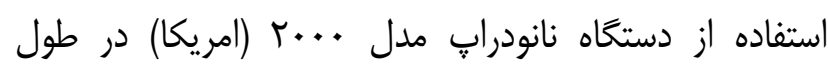

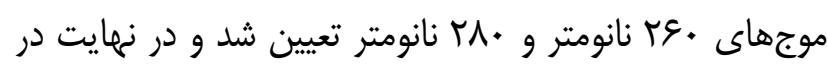

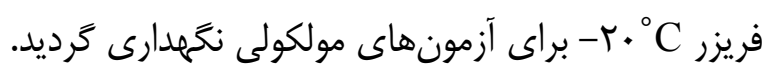

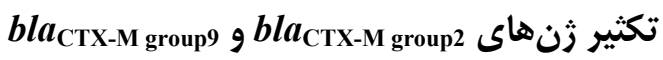
براى تكثير اين زنها از يرايمرهاى سفارش داده شده در

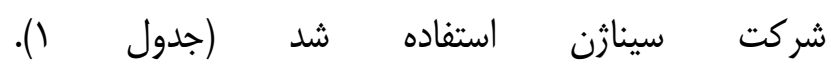
جدول ا- يرايمرهاى بهكار رفته براى تكثير زنهاى Bla

\begin{tabular}{|c|c|c|c|c|}
\hline 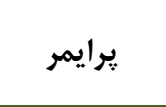 & ثن & توالى اليكَونو كلئوتيدى ('3 - '5) & $\begin{array}{c}\text { اندازه محصول) } \\
\text { PCR (جفت باز) }\end{array}$ & منبع \\
\hline $\begin{array}{l}\text { CTX-M2-F } \\
\text { CTX-M2-R }\end{array}$ & bla ${ }_{\text {CTX-M group2 }}$ & $\begin{array}{l}\text { ATGATGACTCAGAGCATTCG } \\
\text { TGGGTTACGATTTCGCCGC }\end{array}$ & $1 \notin \Delta$ & \multirow[b]{2}{*}{$(I r)$} \\
\hline $\begin{array}{l}\text { CTX-M9-F } \\
\text { CTX-M9-R }\end{array}$ & bla ${ }_{\text {CTX-M group } 9}$ & $\begin{array}{l}\text { ATGGTGACAAAGAGAGTGCA } \\
\text { CCCTTCGGCGATGATTCTC }\end{array}$ & $1<9$ & \\
\hline
\end{tabular}

مقاومت به بتالاكتامازها محسوب مىشود، مىتواند در امر

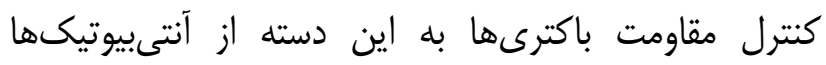
كمك كننده باشد (9). در كل بهدليل كاربرد وسيع سفالوسيورينها در درمان

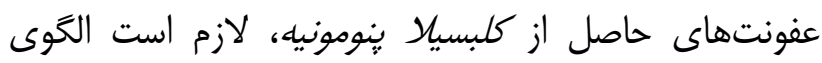

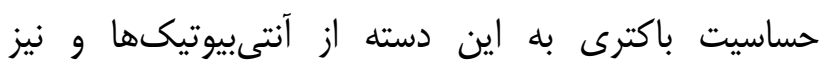
مكانيسمهاى مقاومت به آنها بهطور دائم مورد ارزيابى قرار

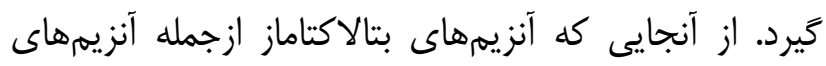

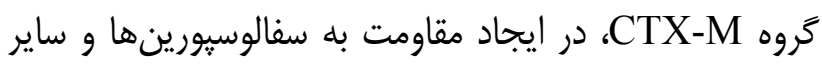
بتالاكتامها نقش بسزايى دارد، بنابراين در مطالعه حاضر ابتدا

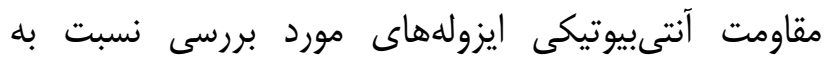

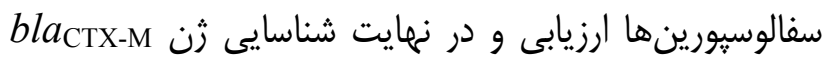

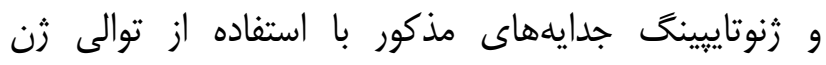
انجام شام شاد انا دلايل مقاومت و نقش اين آنزيمها در

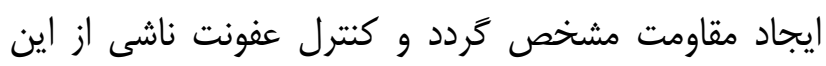
باكترى ها بلهوبى انجام گيرد.

\section{روش تحقيق}

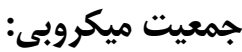

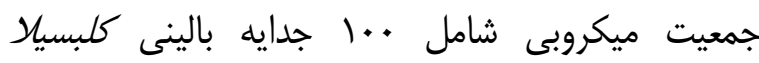
ينومونيه بود كه در مطالعه قبلى ما، از نمونههاى ادرارى

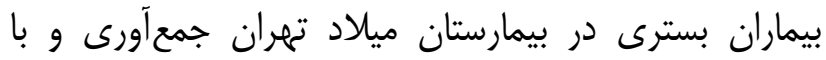

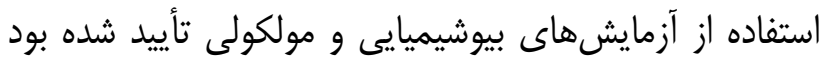

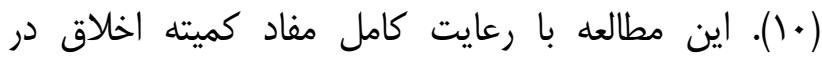
يثوهش و مجوز از كميته اخلاق دانشگاه آزاد واحد علوم دمائه يزشكى تهران (IR.IAU.TMU.REC.1396.278) انجام 


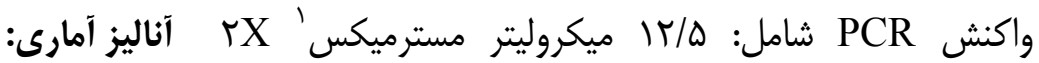

نتايج با استفاده از نرمافزار آمارى SPSS (ويرايش 19 (1)، با كمك آزمون ضريب همبستخى Spearman و آز آزمون Chi-squared

يافته ها

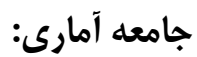

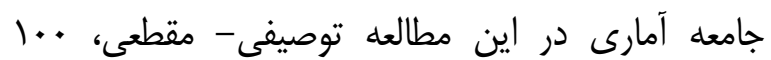

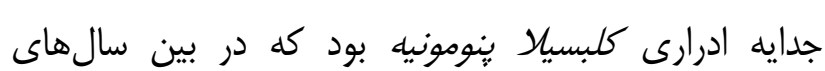

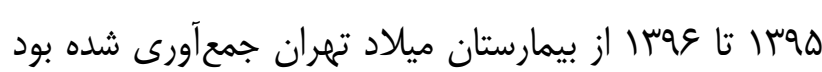

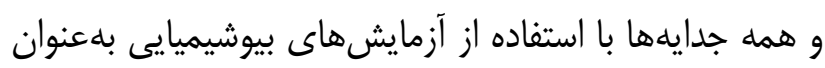
جدايه كلبسيلا بنومونيه تأييد شدند.

\section{نتايج تست آنتىبيوكر ام:}

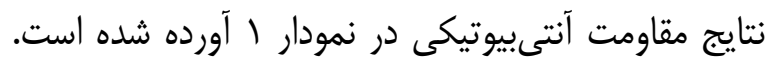

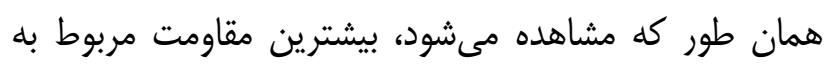

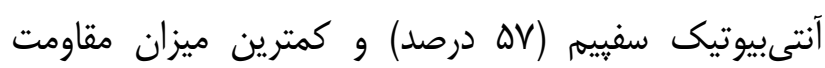

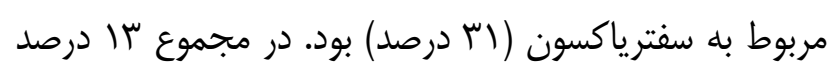

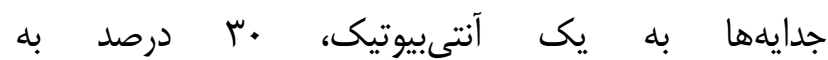

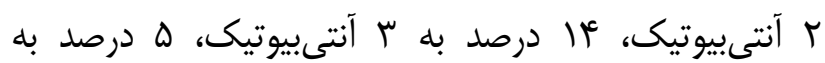

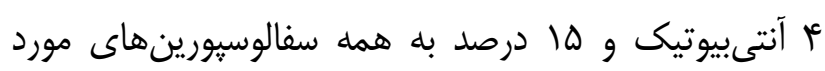

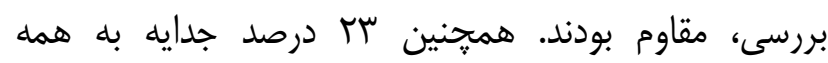

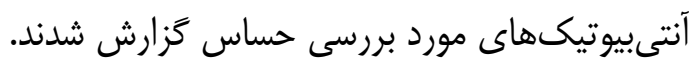

\section{نتايج بر رسى حضور زنهاى}

در الكتروفورز محصول PCR ثنهاى و bla

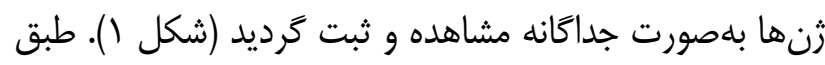

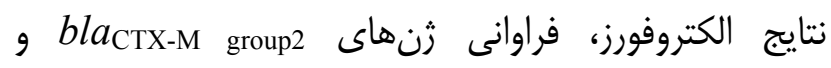
bla CTX-M group9 مجموع از بين ..1 جدايه مورد مطالعه، NV درصد جدايهها

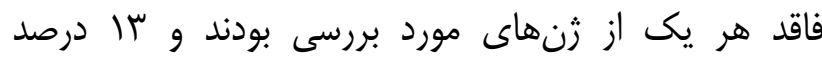

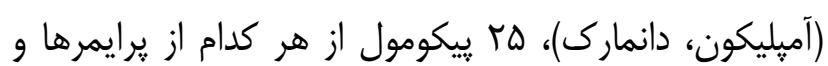

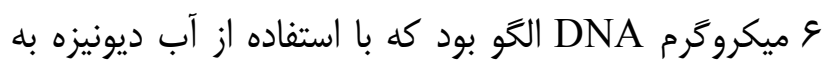

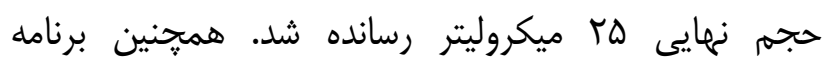
حرارتى PCR بهصورت خلاصه شامل: واسرشت ابتدايى در هو درجه سانتى گراد براى مدت V V دقيقه، זس سيكل تكثيرى

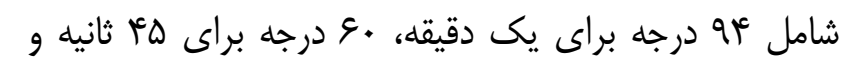

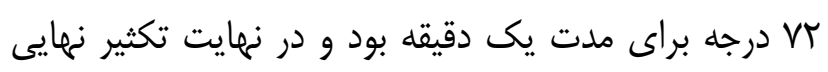

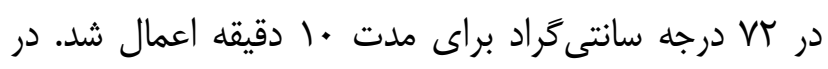

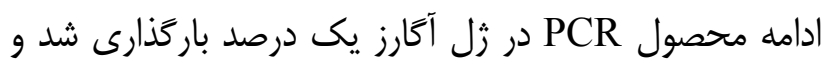

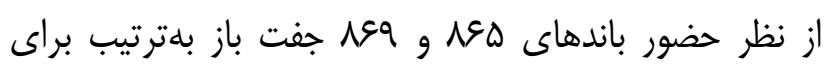

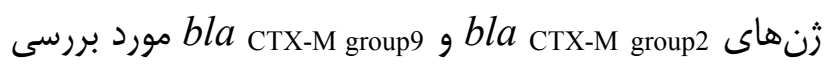
قرار گرفت و حضور و عدم حضور باند بلترتيب بلهصورت اعداد صفر و يك در نرمافزار Excel وارد شد (سرا).

\section{توالىيابى محصول PCR زن bla CTX-M group9}

دو زن bla مربوط به 1 جدايه با استفاده از يرايمرهاى مذكور در حجم ترنم

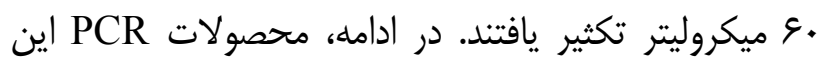

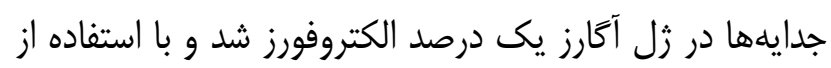
كيت تخليص DNA (سيناثن، ايران)، باند مورد نظر خالص و

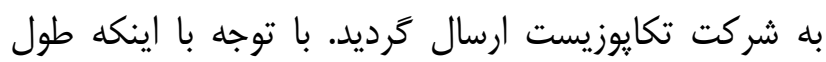

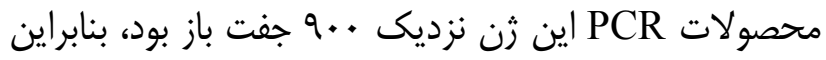

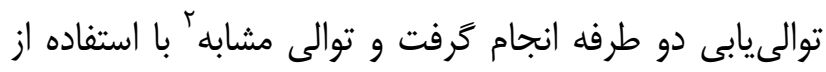

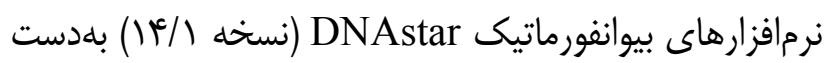

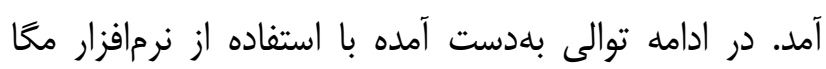

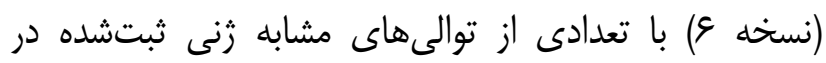

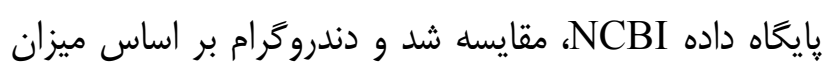

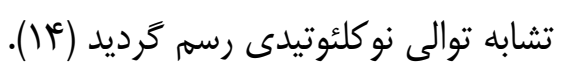

${ }^{1}$ Mastermix
${ }_{2}$ Consensus 


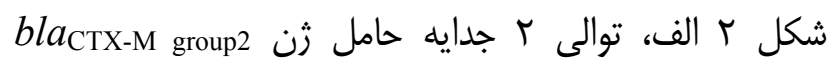

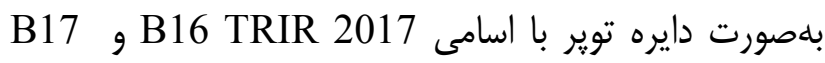
نشان داده شده است. همانطور كه مشاهده TRIR 2017

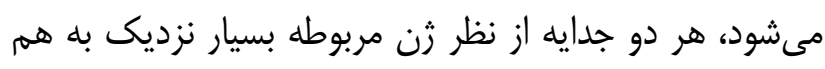

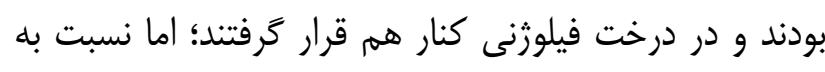

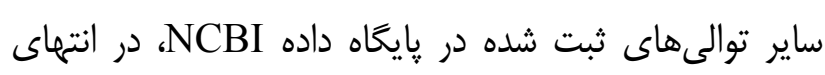

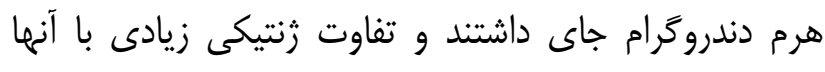

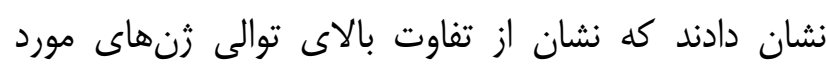
بررسى در اين مطالعه با ساير توالىهاى ثبت شده دارد.
جدايهها يكى از زنها را در بر داشتند.

\section{توالى يابى و زنوتايبينگَ:}

نتايج توالى نوكلئوتيدى r جدايه حامل زن ون group2 DNAstar

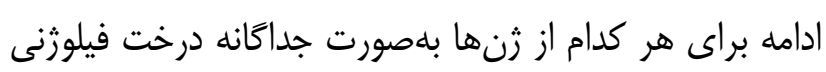
رسم شد. درخت فيلوزنى بر اساس ميزان تشابه توالىها با

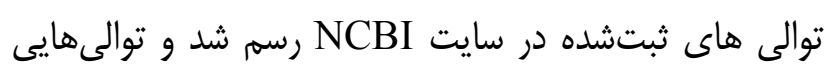
كه تشابهات بيشترى داشتند، نزديك يكديخر قرار گرفتند. در

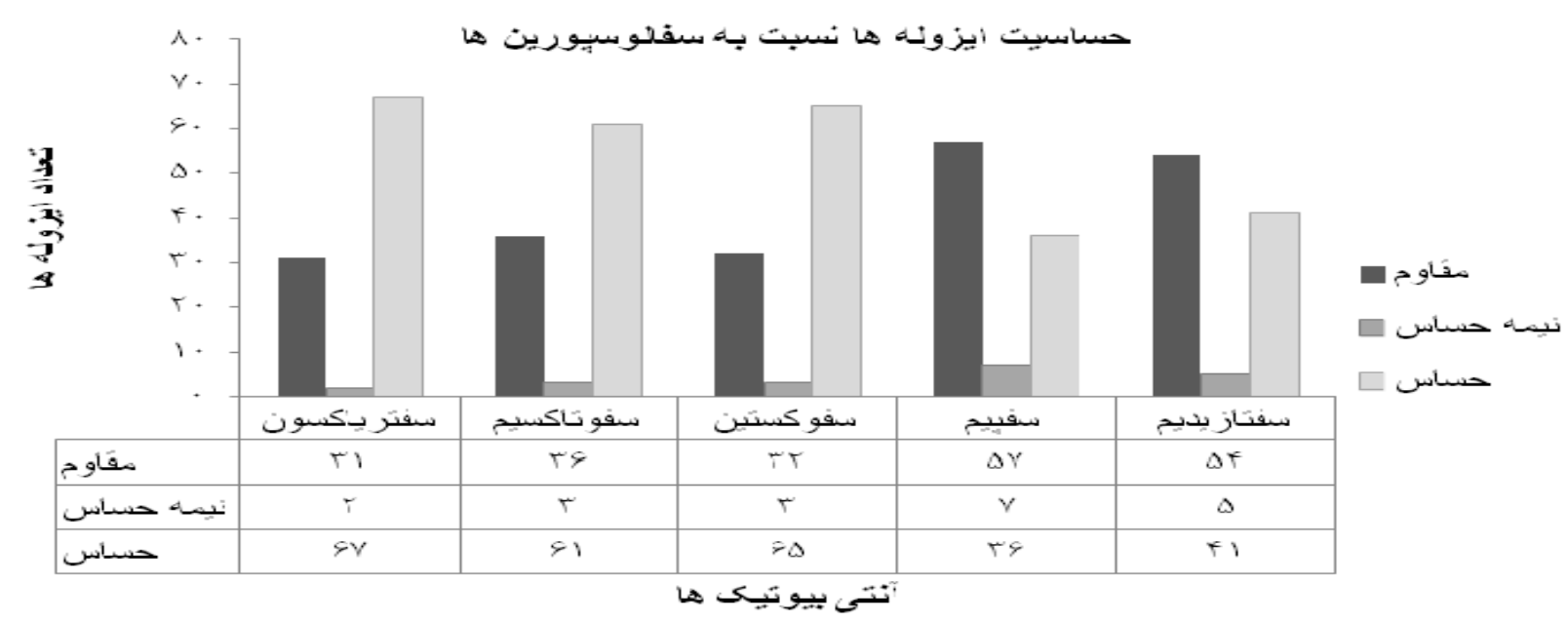

نمودار ا - نتايج تست ديسك ديفيوزن مربوط به +. إ جدايه بالينى كلبسيلا بنومونيه

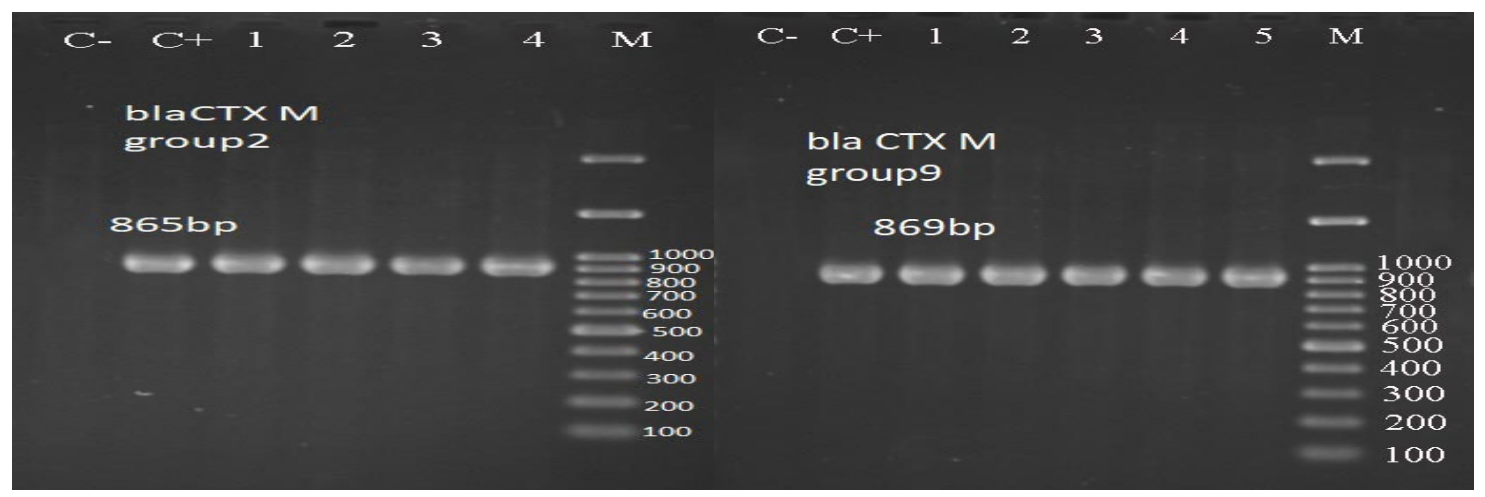

شكل ا- نتايج الكتروفورز محصول PCR مربوط به Pاله

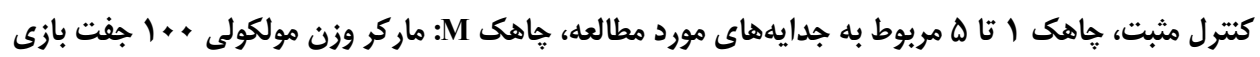




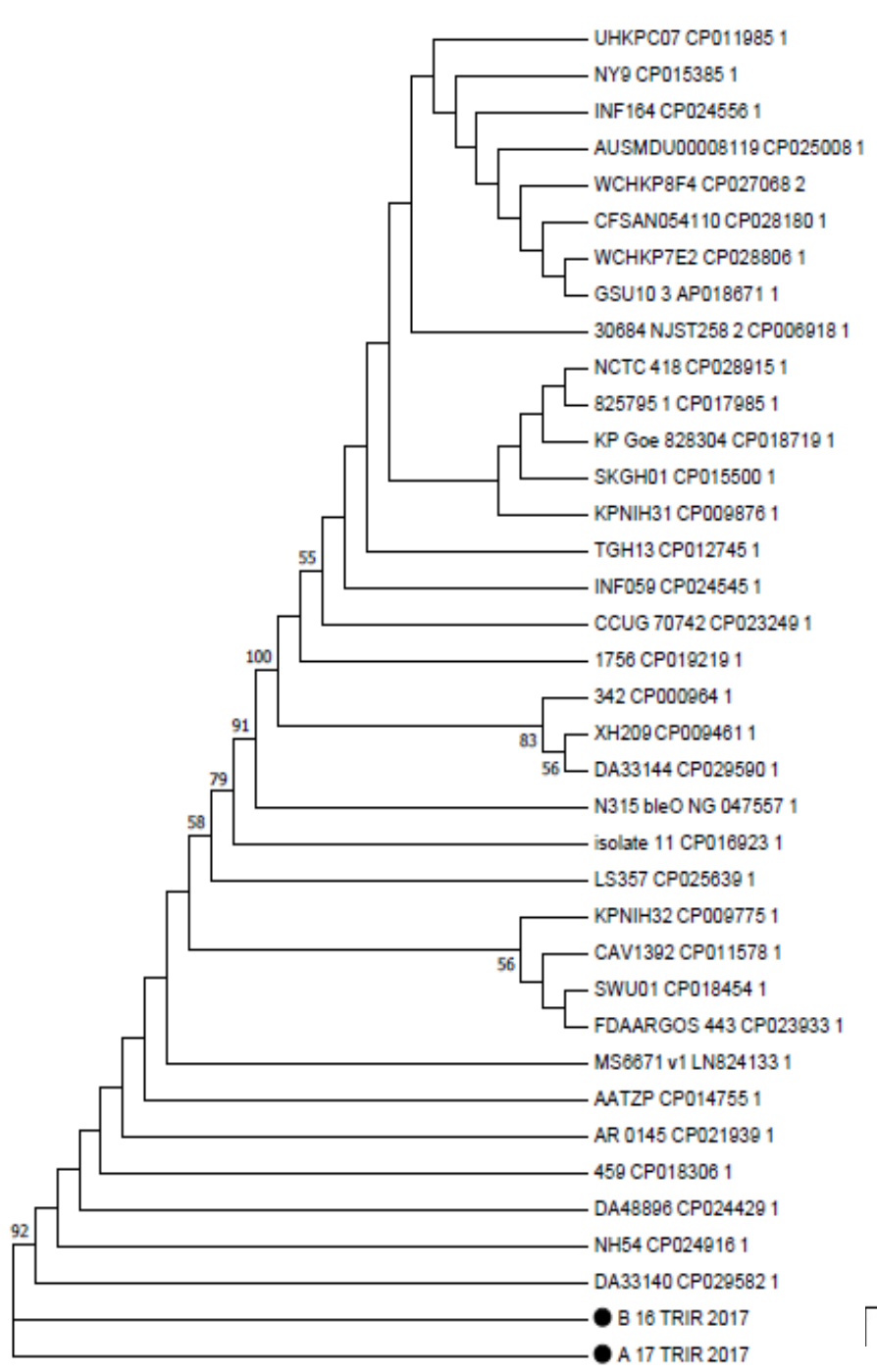

(الف)

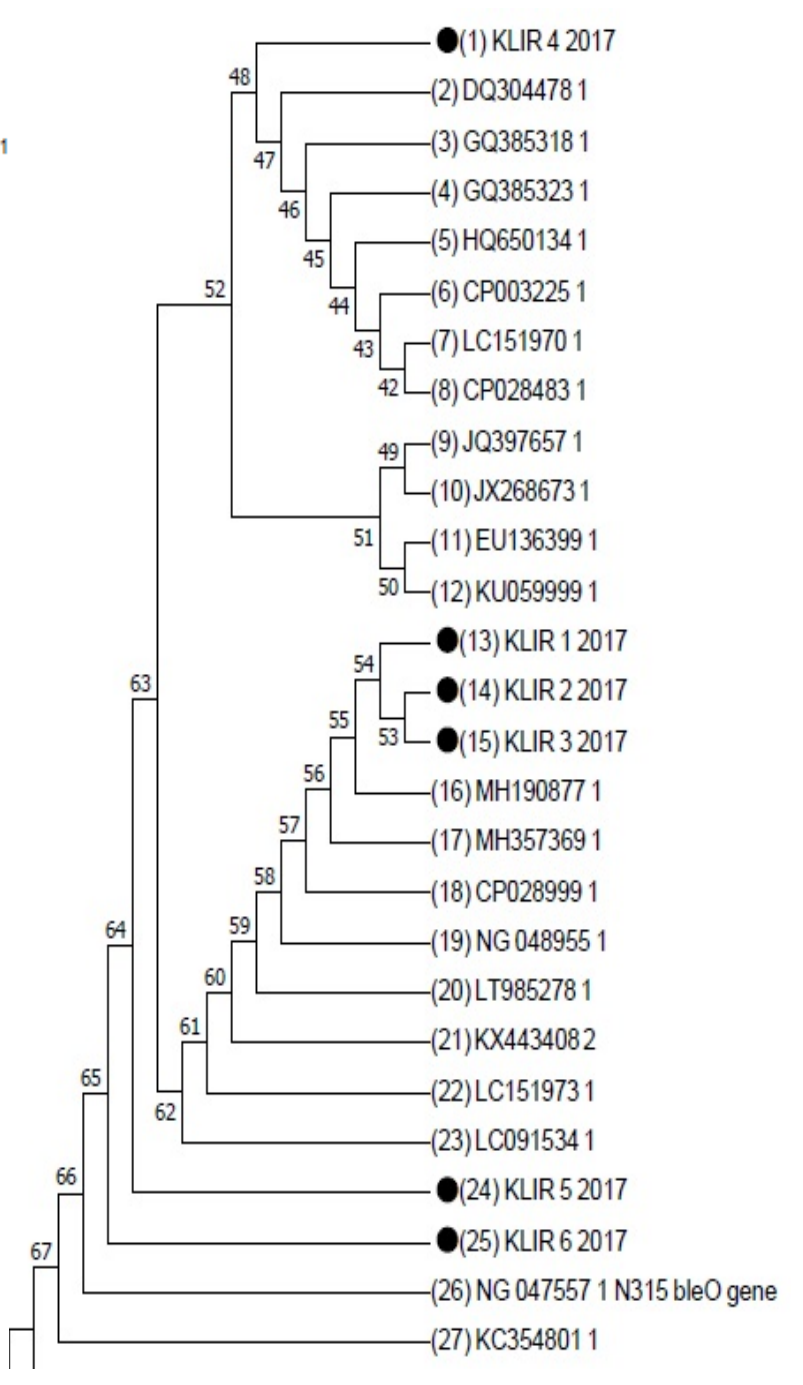

(ب)

شكل r- دندروترامهاى مربوط به توالى دو زن Bla CTX-M group2 (شكل الف) و Bla CTX-M group9 (شكل ب)

زنى يا توالىهاى الحاقى زيادى در آنها رخ داده است.

\section{نتايج آمارى:}

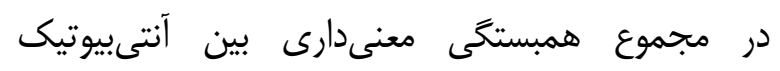

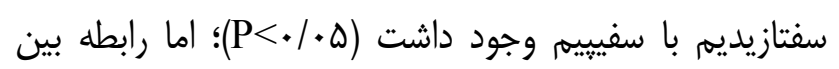
وجود زنهاى bla مقاومت آنتى بيوتيكى معنى دار نبود.
در شكل r ب، 9 جدايه حامل ثن blaCTX-M

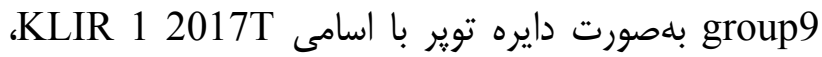
KLIR 4 2017،KLIR 4 ،KLIR 2017 ، 2017 و KLIR 4 نشان داده شده است. در مجموع צ' جدايه مورد بررسى در سه گروه يكتايى، دوتايى و سلتايى قرار

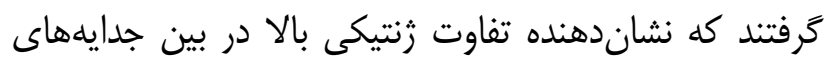
توالىيابىشده از نظر زن كرفئل

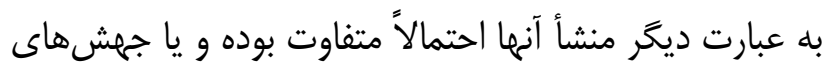


مقاومت به آنتىبيوتيكهاى سفييم و سفتازيديم بلهترتيب

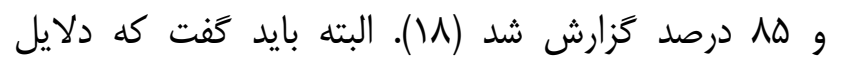

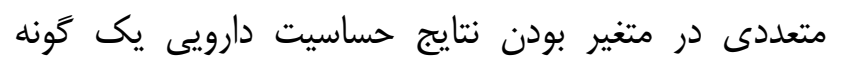

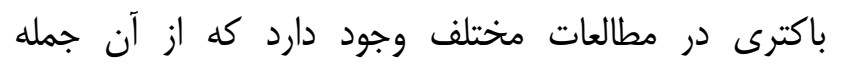

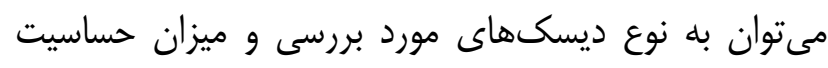

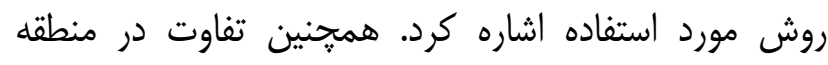

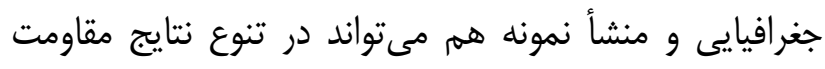

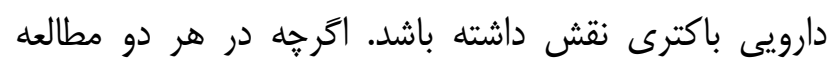

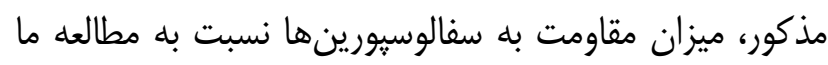

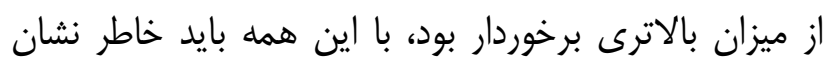

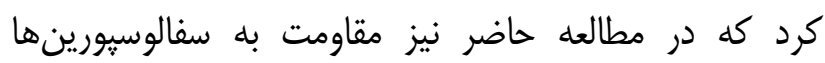

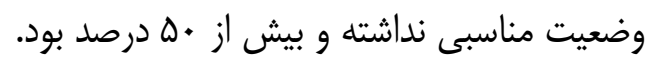

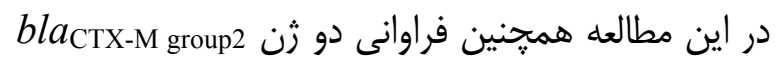
و حاكى از حضور اين ثنها در ايزولههاى مورد بررسى بود. در

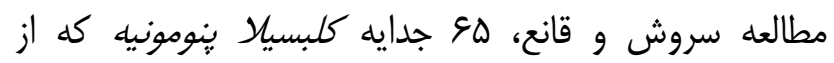
بخش مراقبتهاى ويزه بيمارستانهاى آموزشى تهرئ تهران

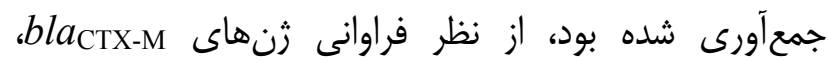

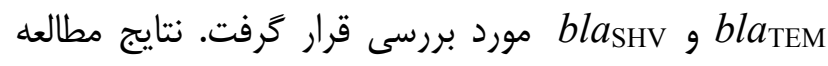

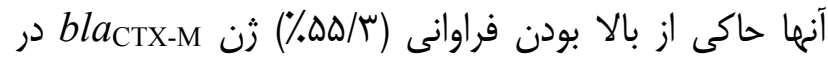

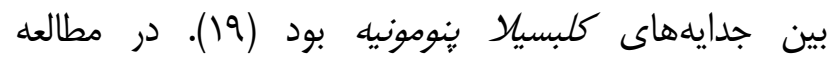

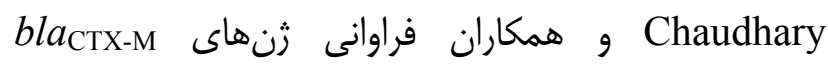
در بين • ل10 جدايه كلبسيل

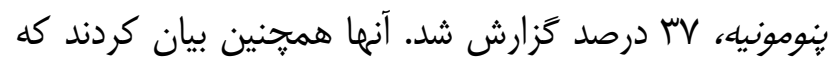

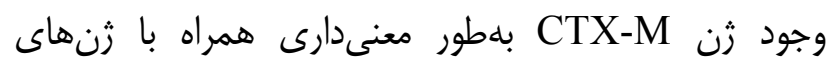

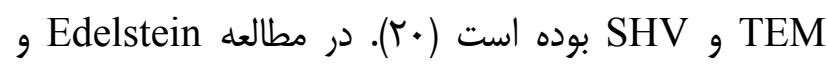

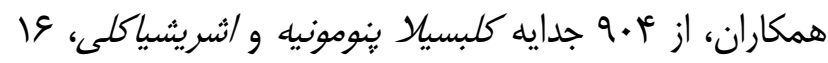

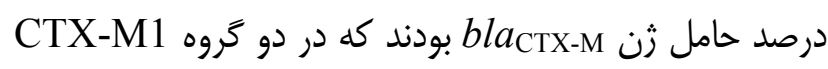
جاى داشتند و در مجموع سهم كلبسيل بنومونيه از /شريشياكلى در داشتن زنهاى CTX-M بيشتر

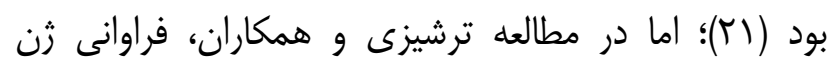
bla $b_{\text {CTX-M }}$
كلبسيلا بنومونيه، يكى از عوامل بيمارىزاى مهرم

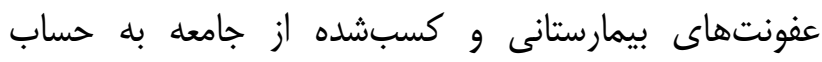

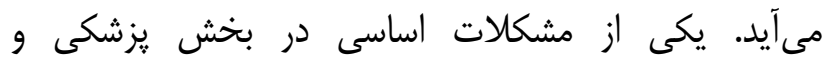

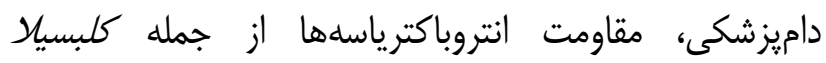

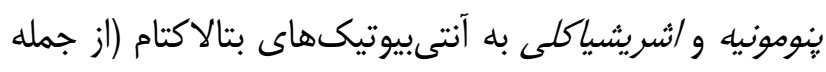

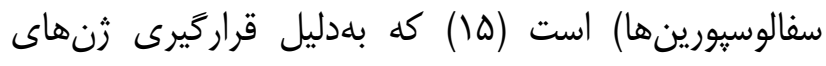

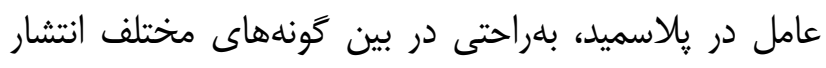

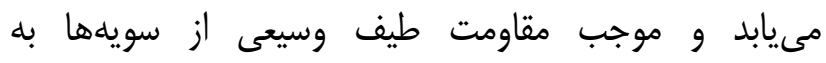

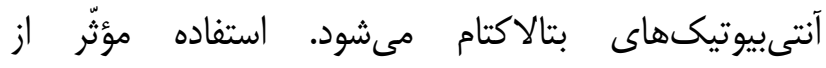

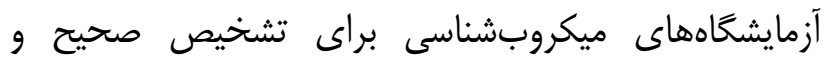

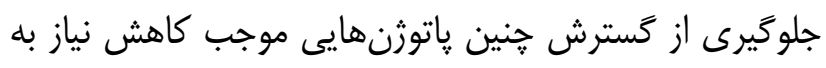

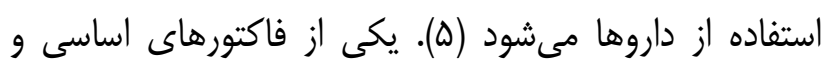

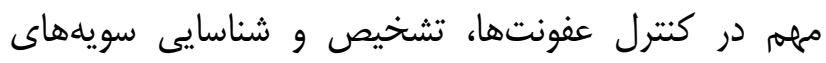
مقاوم است. براى شناسايى مقاومت دارويى باكترى دهنها،

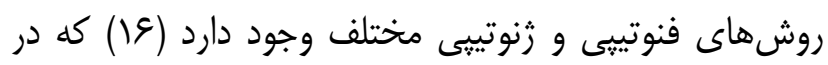
اين مطالعه از هر دو روش فنوتيبى و زنوتيبى براى رئيى شناسايى

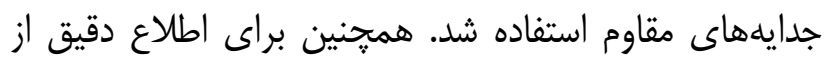

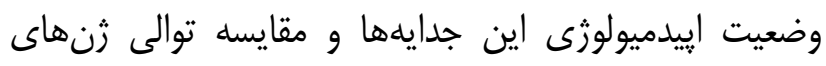
مقاومت با يايگاه داده جهانى (NCBI)، تعدادى ازئ جدائهائها توالىيابى و تاييينگ شدند. در مطالعه حاضر، مقاومت آنتىبيوتيكى تمام +.

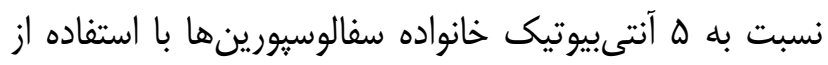

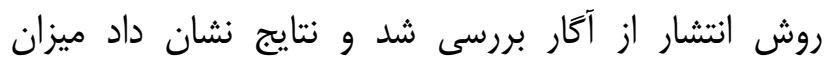

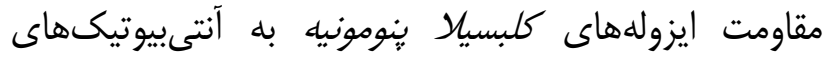
سفييه، سفتازيديم، سفوتاكسيه، سفوكسيتين و سفترياكسون

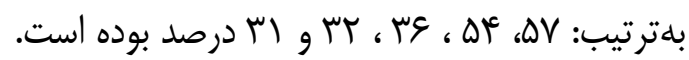
در اين مورد، مطالعهاى كه توسط نجار ييرايه و همكاران

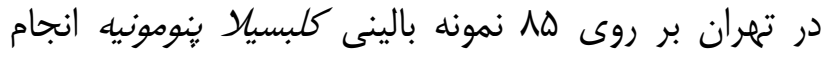

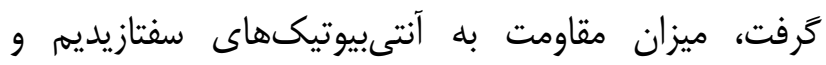

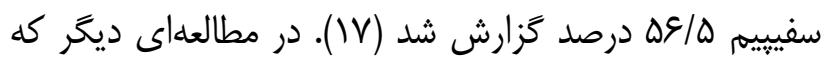
توسط فيضآبادى و همكاران در تهران انجام كرفت، ميزان 
bla group2

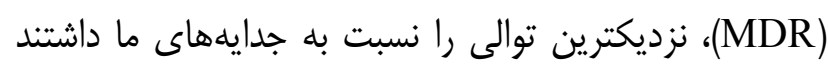

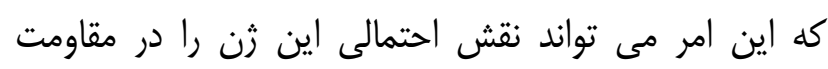

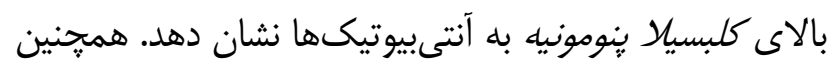

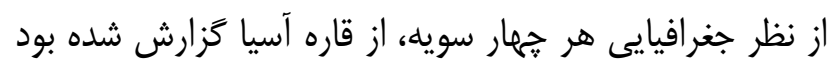

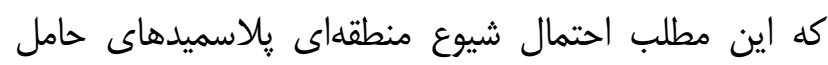

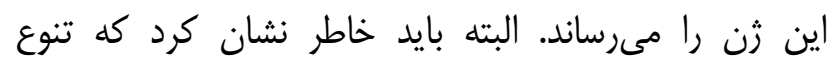

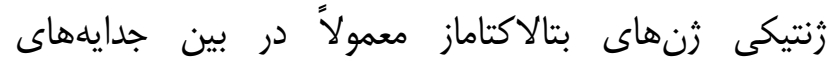

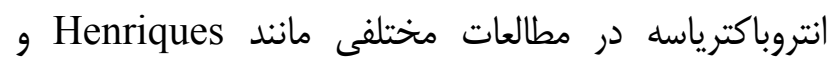

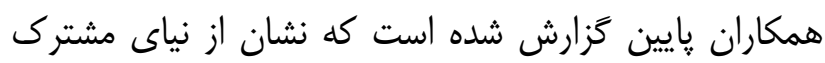

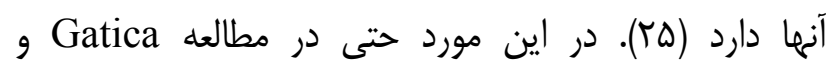

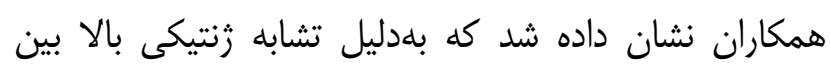
ثنهاى بتالاكتاماز در جدايههاى غير بالينى و بالينى، احتمال

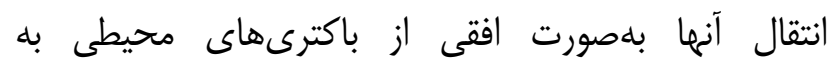

باكترىهاى عامل مولد بيمارى انسانى وجود دارد (عَ). در دندروگرام bla

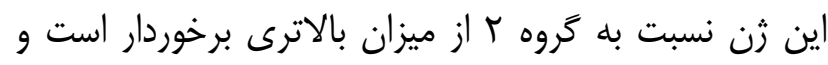

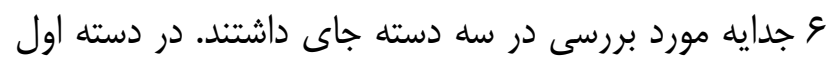
KLIR 4 سويه كلبسيلا ينومونيه ثبت شده در جين بود. در دسته دوم

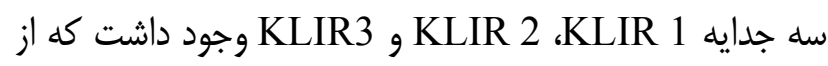
نظر توالى نو كلئوتيدى مشابه زن جلن

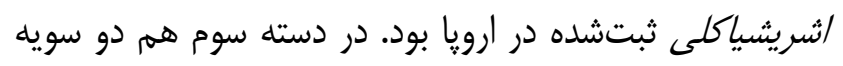
KLIR 5

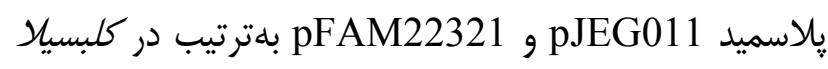

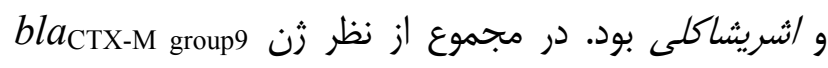

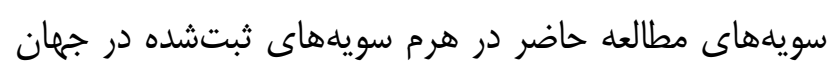

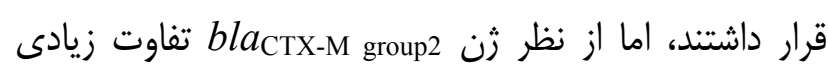

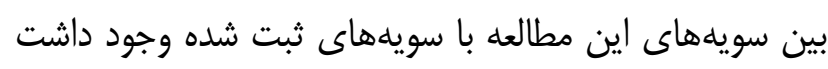

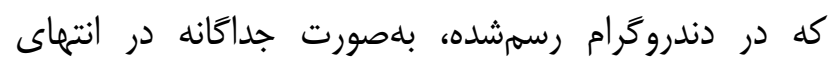

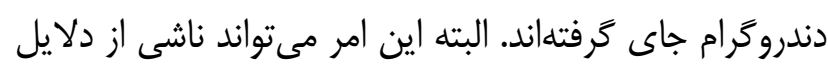

قرار گرفت و نتايج نشان داد كه فراوانى اين زن در بين

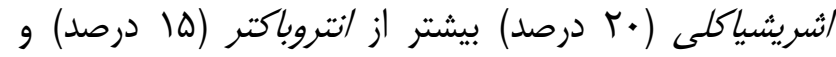

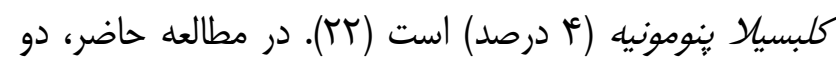

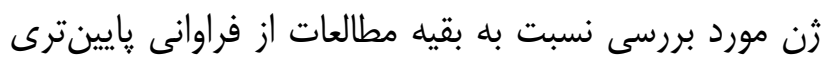

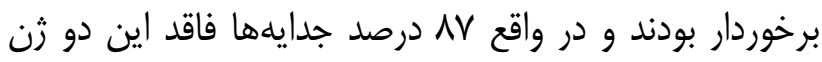

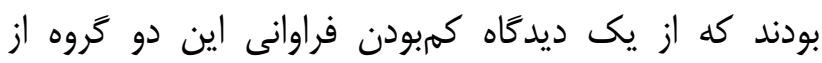
زنهاى bla CTX-M مطلوب به نظر مىرسد، اما به دليل اينكه دونه

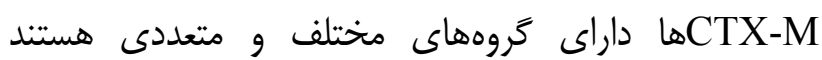
بنابراين براى آكاهى و اطلاع دقيق از وضعيت شيوع اين

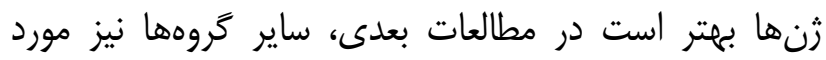
بررسى و آناليز قرار گيرد تا براى كنترل وضعيت درات بتالاكتامازها تصميم بهتر و كارشناسى شده انجام گيرد.

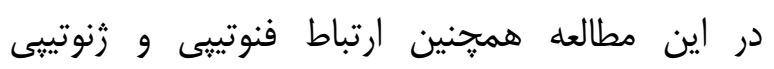

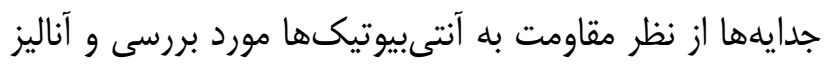

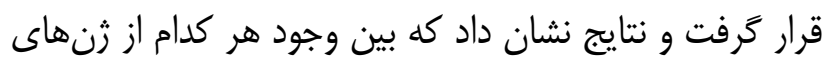

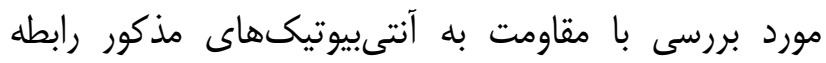

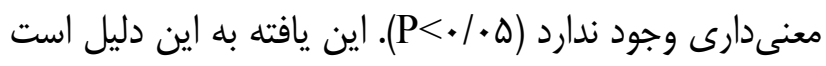

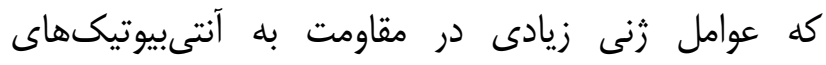

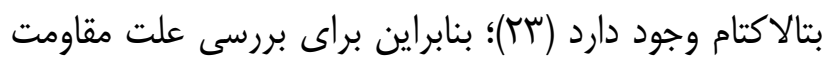
دارويى، بهتر است مكانيسمهاى مقاومت متعددى بررسى دامى

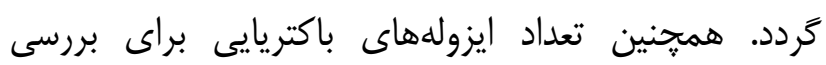

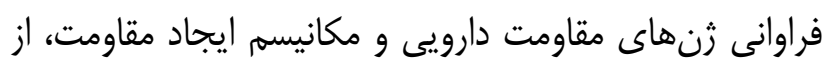

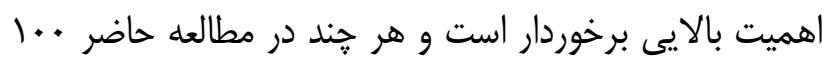

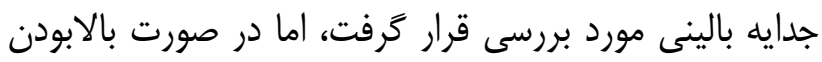

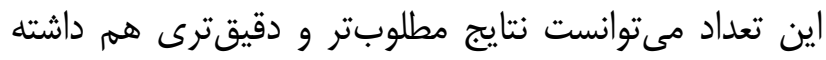
باشد. با اين همه، همبستخى معنى دارى بين مقاومت بله

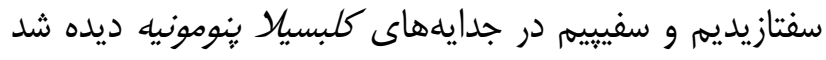
كه يكى از دلايل وجود همبستخى بين آنتىبيوتيكها، مىتواند ناشى از حمل پيلاسميدهاى مقاومت مشابه در بين

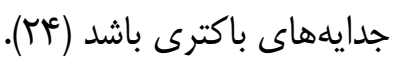

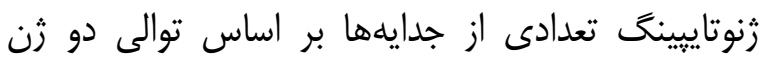

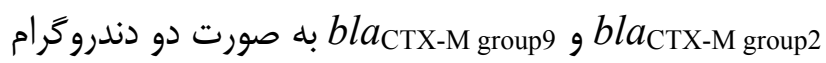




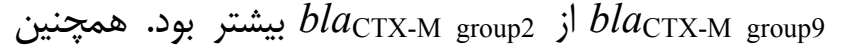
بلهدليل تشابه جدايههاى كلبسيلاينومونيه از نظر توالى نوكلئوتيدى زنهاى بتالاكتاماز در اين مطالعه با سويههاى MDR ثبتشده در MDR

$$
\text { كلبسيلا در تهران بيشتر است. }
$$

\section{ثقل ير و تشكر}

اين مقاله برگرفته از پاياننامه دانشجويى مقطع

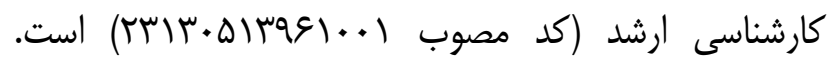

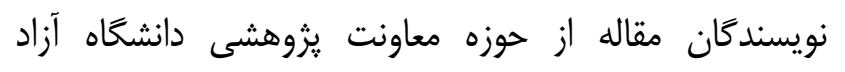

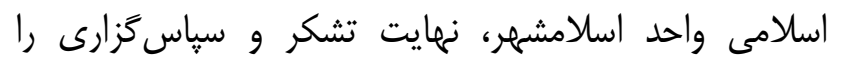
دارند. تضاد منافع نويسندكان اعلام مىدارند هيج گونه تضاد منافعى در يزوهش حاضر وجود ندارد. متفاوتى مانند توالىهاى الحاقى و جهشهاى نقطهاى باشد. همجنين بهدليل مطالعات نادر در مورد توالى زنهاى بتالاكتاماز در ايران، هيج جدايهاى از ايران در دندروگرام رسمشده براى دو زن مورد مطالعه مشاهده نشد.

در مجموع در اين مطالعه نتايج مقاومت آنتىبيوتيكى نشان داد كه سفالوسيورينها كه جزء داروهاى یركاربرد در درمان كلبسيلا ينومونيه هستند، كمكم اثر خود را در درمان اين نوع از عفونتها از دست مىدهند و احتمال افزايش مقاومت به اين خانواده در آينده زياد است. اخرجه فراوانى زنهاى جدايههاى مورد مطالعه زياد نبود، ولى بلددليل مقاومت فنوتييى بالا به اين آنتىبيوتيكها، احتمال وجود ساير زنهاى مرتبط با مقاومت به سفالوسيورينها در بين اين جدايهها بيشتر است. در توالىيابى هم مشخص شد كه تيڤهاى متنوعى از اين زنها در ايران وجود دارد كه البته تنوع زنتيكى

1- Li B, Zhao Y, Liu C, Chen Z, Zhou D. Molecular pathogenesis of Klebsiella pneumoniae. Future Microbiol. 2014; 9(9): 1071-81. doi: 10.2217/fmb.14.48.

2- Vuotto C, Longo F, Pascolini C, Donelli G, Balice MP, Libori MF, et al. Biofilm formation and antibiotic resistance in Klebsiella pneumoniae urinary strains. J Appl Microbiol. 2017; 123(4): 1003-18. doi: 10.1111/jam.13533.

3- Drieux L, Brossier F, Sougakoff W, Jarlier V. Phenotypic detection of extended-spectrum $\beta$-lactamase production in Enterobacteriaceae: review and bench guide. Clin Microbiol Infect. 2008; 14 Suppl 1: 90-103. doi: 10.1111/j.14690691.2007.01846.x

4- Díaz-Agero Pérez C, López-Fresneña N, Rincon Carlavilla AL, Hernandez Garcia M, Ruiz-Garbajosa P, AranazAndrés JM, et al. Local prevalence of extended-spectrum beta-lactamase (ESBL) producing Enterobacteriaceae intestinal carriers at admission and co-expression of ESBL and OXA-48 carbapenemase in Klebsiella pneumoniae: a prevalence survey in a Spanish University Hospital. BMJ open. 2019; 9(3): e024879. doi: 10.1136/bmjopen-2018024879.

5- Paterson DL, Ko WC, Von Gottberg A, Casellas JM, Mulazimoglu L, Klugman KP, et al. Outcome of cephalosporin treatment for serious infections due to apparently susceptible organisms producing extended-spectrum $\beta$-lactamases: implications for the clinical microbiology laboratory. J Clin Microbiol. 2001; 39(6): 2206-12. DOI: 10.1128/JCM.39.6.2206-2212.2001

6- Swanson E, Freeman L, Seleem M, Guba Jr A, Morris S, Yang D, et al. Extended-spectrum beta-lactamases: a clinical update. J Am Vet Med Assoc. 2014; 244(10): 1126-7. doi: 10.2460/javma.244.10.1126

7- Hakimi Alni R, Ghobadi N, Najafi Asl M, Sharifi A. Genotyping of Escherichia coli isolated from human and water samples using ERIC-PCR method in Hamadan city. J Birjand Univ Med Sci. 2018; 25(4): 297-306. [Persian] 
8- Hakimi Alni R, Mohammadzadeh A, Mahmoodi P. Molecular typing of Staphylococcus aureus of different origins based on the polymorphism of the spa gene: characterization of a novel spa type. 3 Biotech. 2018; 8(1): 58. doi: 10.1007/s13205-017-1061-6.

9- Poirel L, Gniadkowski M, Nordmann P. Biochemical analysis of the ceftazidime-hydrolysing extended-spectrum $\beta$ lactamase CTX-M-15 and of its structurally related $\beta$-lactamase CTX-M-3. J Antimicrob Chemother. 2002; 50(6): 1031-4. DOI: $10.1093 / \mathrm{jac} / \mathrm{dkf} 240$

10- Amiri M, Ghane M, BabaeeKhou L. Molecular typing and investigating the presence of efflux genes in urinary isolates of Klebsiella pneumoniae. J Urmia Univ Med Sci. 2019; 30(1): 8-20. [Persian]

11- CLSI. Performance Standards for Antimicrobial Susceptibility Testing; Twenty-Fifth Informational Supplement. CLSI document M100-S25. Wayne, PA: Clinical and Laboratory Standards Institute; 2015.

12- Ribeiro Junior JC, Tamanini R, Fritegoto Soares B, Marangon de Oliveira A, de Godoi Silva F, Fernandes da Silva F, et al. Efficiency of boiling and four other methods for genomic DNA extraction of deteriorating spore-forming bacteria from milk. Semina: Ciências Agrárias. 2016; 37(5): 3069-78. doi: 10.5433/1679-0359.2016v37n5p3069

13- Guessennd N, Bremont S, Gbonon V, Kacou-Ndouba A, Ekaza E, Lambert T, et al. [Qnr-type quinolone resistance in extended-spectrum beta-lactamase producing enterobacteria in Abidjan, Ivory Coast]. Pathol Biol (Paris). 2008; 56(7-8): 439-46. [French] doi: 10.1016/j.patbio.2008.07.025.

14- Grillová L, Bawa T, Mikalová L, Gayet-Ageron A, Nieselt K, Strouhal M, et al. Molecular characterization of Treponema pallidum subsp. pallidum in Switzerland and France with a new multilocus sequence typing scheme. PloS one. 2018; 13(7): e0200773. doi: 10.1371/journal.pone.0200773.

15- Wyres KL, Holt KE. Klebsiella pneumoniae population genomics and antimicrobial-resistant clones. Trends Microbiol. 2016; 24(12): 944-56. doi: 10.1016/j.tim.2016.09.007.

16- Lee CR, Lee JH, Park KS, Kim YB, Jeong BC, Lee SH. Global dissemination of carbapenemase-producing Klebsiella pneumoniae: epidemiology, genetic context, treatment options, and detection methods. Front Microbiol. 2016; 7: 895. doi: 10.3389/fmicb.2016.00895.

17- Najar-Peerayeh S, Derakhshan S, Fallah F, Bakhshi B, Alebouyeh M. Prevalence of Extended-Spectrum $\beta$ Lactamases Among Klebsiella pneumoniae Isolated from Intensive Care Unit Patients in a Tertiary Hospital. Arch Clin Infect Dis. 2019; 14(1):e69199. doi: 10.5812/archcid.69199.

18- Feizabadi MM, Mahamadi-Yeganeh S, Mirsalehian A, Mirafshar SM, Mahboobi M, Nili F, et al. Genetic characterization of ESBL producing strains of Klebsiella pneumoniae from Tehran hospitals. J Infect Dev Ctries. 2010; 4(10): 609-15.

19- Soroush Z, Ghane M. Molecular identification of CTX-M, TEM and SHV $\beta$-lactamases in Klebsiella pneumoniae isolated from respiratory system of patients in the ICU of educational hospitals in Tehran. Feyz. 2017; 21(3): $232-9$. [Persian]

20- Chaudhary M, Payasi A. Antimicrobial susceptibility patterns and molecular characterization of Klebsiella pneumoniae clinical isolates from north Indian patients. Int J Med Med Sci. 2013; 46(2): 1218-24.

21- Edelstein M, Pimkin M, Palagin I, Edelstein I, Stratchounski L. Prevalence and molecular epidemiology of CTX-M extended-spectrum $\beta$-lactamase-producing Escherichia coli and Klebsiella pneumoniae in Russian hospitals. Antimicrob Agents Chemother. 2003; 47(12): 3724-32. doi: 10.1128/aac.47.12.3724-3732.2003

22- Torshizi R, Zamanzad B, Mokhtareyan K, Karimi A. Determination of CTX-M genes in Enterobacteriaceae producing extended-spectrum beta-lactamase using PCR method. J Shahrekord Univ Med Sci. 2011; 3(13): 9-17. [Persian]

23- Falagas ME, Karageorgopoulos DE. Extended-spectrum $\beta$-lactamase-producing organisms. J Hosp Infect. 2009; 73(4): 345-54. doi: 10.1016/j.jhin.2009.02.021.

24- Hosseini Jazani N, Omrani MD, Yekta Z, Nejadrahim R, Afshar Yavari SH, Zardashti M. Plasmid profile of Pseudomonas aeruginosa and its relation with antibiotic resistance in hospital isolates. J Kerman UnivMed Sci. 2008; 15(1): 9-17. [Persian] 
25- Henriques IS, Fonseca F, Alves A, Saavedra MJ, Correia A. Occurrence and diversity of integrons and $\beta$-lactamase genes among ampicillin-resistant isolates from estuarine waters. Res Microbiol. 2006; 157(10): 938-47. DOI: 10.1016/j.resmic.2006.09.003

26- Gatica J, Jurkevitch E, Cytryn E. Comparative Metagenomics and Network Analyses Provide Novel Insights Into the Scope and Distribution of beta-Lactamase Homologs in the Environment. Front Microbiol. 2019; 10: 146. doi: 10.3389/fmicb.2019.00146. 